\title{
EVOLUTION IN THE REGULATORY FRAMEWORK FOR DISTANCE LEARNING IN A PANDEMIC ENVIRONMENT - THE EXPERIENCE OF BULGARIA
}

\author{
Andrey Zahariev ${ }^{\mathbf{1}^{*}}$, Petya Ivanova ${ }^{2}$, Angel Angelov $^{3}$ and Galina Zaharieva ${ }^{4}$ \\ ${ }^{1}$ Prof. Dr., D. A. Tsenov Academy of Economics, Svishtov, Bulgaria, \\ andrey.zahariev.1971@gmail.com \\ ${ }^{2}$ Assoc. Prof. Dr., D. A. Tsenov Academy of Economics, Svishtov, Bulgaria, p.ivanova@uni- \\ svishtov.bg \\ ${ }^{3}$ Assoc. Prof. Dr., D. A. Tsenov Academy of Economics, Svishtov, Bulgaria, a.angelov@uni- \\ svishtov.bg \\ ${ }^{4}$ Assoc. Prof. Dr., D. A. Tsenov Academy of Economics, Svishtov, Bulgaria, g.zaharieva@uni- \\ svishtov.bg \\ ${ }^{*}$ Corresponding Author
}

\begin{abstract}
In higher education, students and doctoral students are a key factor in testing and developing innovative research methods and pedagogical techniques. Their focus is on the present and future of educational technology in its historical variation from face-to-face learning, through distance learning (d-learning), elearning (e-learning), mobile learning (m-learning) and u-learning (u-learning). The full-time form, the parttime form and the distance learning form are imposed as forms of education in the European Higher Education Area. Distance learning is inherently one of the most attractive forms of higher education. Its technological richness and the absence of a direct need to leave the workplace or place of residence provide an increasing opportunity for its use by managers, professionals, and "lifelong learners". This calls for a national regulation of distance learning in higher education. The main aim of the paper is to analyse the Bulgarian experience in the national regulation of distance learning in higher education from the first national ordinance enforced in 2004 and the new Cvid-19 in medias ordinance from 2021. In 2004, distance learning was defined as an organization of the learning process in which the student and the teacher are separated in terms of their location, but not necessarily in terms of time, as the distance created is compensated by technological means. The Covid-19 pandemic, as well as the current trends in digital technology, combined with strategic documents at national and European level, logically necessitate an update of the regulatory framework for distance learning in the EU member states and in particular in the Republic of Bulgaria. Based on one-year discussions within a working group of representatives of the Ministry of Education and Science, the National Centre for Distance Learning and leading universities in terms of experience and technology, a new Ordinance on state requirements for organizing distance learning in of higher education has been developed and adopted in 2021. The ordinance is also coordinated with the National Agency for Evaluation and Accreditation. The role of the agency is to assess the distance form of education in two stages assessing the level of the environment in the respective higher school and assessing the opportunities for conducting distance learning in a specific professional field or specialty of the regulated professions. The new ordinance published in the State Gazette in March 2021 (in force since September 1, 2021) provides a new definition of the distance-learning form of higher education, which is specified in three separate paragraphs. It is defined that "a form of higher education in which students, teachers and administrators can be separated by location, but not necessarily by time, as the distance created is compensated by technologies, methods and means of e-learning". The role of digital technologies has been introduced "Distance learning is realized through digital technologies for managing the learning process, based on a system of different type, location and time of use of human, material and information activities and
\end{abstract}


resources." The process approach is integrated in teaching - "To compensate for the distance, the higher schools model the respective educational and administrative activities as information processes and implement them through information and communication technologies." In addition to award higher education degrees, higher education institutions are allowed to organize distance learning and to improve the qualification of specialists with higher education, as well as for continuing and additional professional training. In view of the degree of information and technological provision in the implementation of distance learning, the environment for its implementation is classified into four levels. They are bound by the right to conduct training for the acquisition of the relevant degrees of higher education. The possibility for remote conducting of semester and final state examinations and videoconference defence of diploma theses is regulated. As a result of the new regulation, a triple positive effect was achieved. Students improve their digital skills for working in an electronic environment. It has a positive effect on teachers as qualification and skills for work through the means of e-learning, lecture courses are digitalized. Higher education institutions implement simultaneously the government policy for increasing the quality of education, the efficiency of the organization of the educational process and the administrative procedures. Finally, the national information and educational infrastructure is being improved, which helps to connect them in European and global networks for higher education. The main conclusion of the study is that the Covid-19 and the new regulation of distance learning pushed forward all Bulgarian universities on the road of fast digitalization and introduction of the most advanced e-learning technologies.

Keywords: E-Learning, Covid-19, Distance Learning

\section{INTRODUCTION}

The contemporary university education is a stress test for young generations to be prepared for a career in a society with fast digitalization and technological changes. Usually students and doctoral students are a key factor in testing and developing innovative research methods and pedagogical techniques. From evolutionary point of view, students are the driving force of educational technology in its historical variation from face-to-face learning, through distance learning (d-learning), e-learning (e-learning), mobile learning (mlearning) and u-learning (u-learning). The fulltime form, the part-time form and the distance learning form are imposed as forms of education in the European Higher Education Area and in all national Laws of Higher Education into EU27. In the latest decades, the distance learning form has assumed the role of one of the most attractive forms of higher education. Its technological richness, the absence of a direct need to leave the workplace or place of residence provides an increasing opportunity for its use by managers, professionals and people studying in the context of the concept of "lifelong learning". All this is integrated under the framework of national regulation of distance learning in higher education. The main aim of the paper is to analyse the Bulgarian experience in the national regulation of distance learning in higher education from the first national ordinance from 2004 and the new Cvid-19 in medias ordinance from 2021.

\section{REGULATION OF THE DISTANCE LEARNING - FROM EVOLUTION TO REVOLUTION}

\subsection{The first National Ordinance in Distance Learning as a Bases for Starting e- Learning Degrees in Bulgarian Higher Education Institutions}

Bulgaria's experience in the national regulation of distance learning in higher education dates back to a national ordinance from 2004 and a new ordinance from 2021. In 2004, distance learning was defined as an organization of the learning process in which the student and the teacher are separated by location, but not necessarily by time, as the distance created is compensated by technological means. The first ordinance is step-by-step developed document based of the 10 years result of "PHARE Multi-Country Programme for Distance Education" (European Training Foudation, 1999) where several Bulgarian higher education institution introduced the best international practices for distance learning and developed own educational know-how.

The main idea is to introduce and accept the distance learning as a technological solution based on the modern possibilities of information exchange in a network environment. It is orientated to the latest requirement to the human resources in the beginning of $21^{\text {st }}$ century (Zahariev \& Zaharieva, 2003, pp. 5-36). Presented through the positions of the normative regulation is imposing new standards and understandings for the structure of the teaching hours, in terms of their intensity and dynamics, in terms of the transition from one component to another and management of their aftermath, cyclicity and commitment. This requires a 
rethinking of the leading strategic goal of modern education in the implementation of the new paradigm for post-bachelor's degrees - "Learning through research - research through learning." The main sub-goals of the new paradigm are formulated as follows: 1. Creation of a profiled training material base, provided with specialized software, hardware, library units and access to databases; 2 . Strategic transformation of the quality of education through transition from traditional techniques to training based on the use of new information technologies; 3. Development of updated curricula with enhanced interactive element of training in the blocks of special, specializing and master's disciplines; 4. Improving the conditions for conducting research supporting the educational process, adequate to the world standards in the field.

As main measures for ensuring the formation of the sub-goals for increasing the competitiveness of the institution and the educational product under first attempt of distance learning regulation are defined: 1 . Administrative provision of the education and training of specialists with higher education at national and international level. 2. Development of modern, highly efficient and competitive information technologies for training. 3. Dissemination of profiled knowledge among target groups of users. 4. Planning and organization of the educational-methodical, scientific and financial activities on the distance learning within the defined powers. 5. Methodical support of the leading departments in the training in master's programs - distance form. 6. Implementation of coordination, provision and conduct of fundamental and auxiliary research on the creation and adaptation of existing teaching materials for the purposes of distance learning. 7. Formation and management of a system for practical development of information-based tools and other scientific and technical products in the field of distance learning, developed in higher schools in order to increase the security and quality of the learning process. 8. Development and implementation of new and adaptation of existing methodologies, curricula and training programs and courses for distance learning. 9. Preparation of manuscripts and teaching materials, development and distribution of software and audio-visual production in the programs and courses of distance learning. 10. Organizational and methodological support of the new forms of education with predominant use of modern information technologies. 11. Organization and conducting of scientific exchange, internships and conferences for leading specialists in the field of modern educational and information technologies.

The debate on the quality of higher economic education inevitably raises the issue of evaluation criteria. These criteria can have their academic but also their market orientation. Quality assurance standards for distance learning are formed in relation to three aspects, in line with ISO conformity procedures: a) input resources (what is the preparation of prospective students); b) method of training, incl. compliance with accreditation; c) results of the outcome (what the graduates know and are able to do).

The application of the results-based management approach focuses on the third group of standards. Outputoriented standards (graduates' competencies) should include: a) General academic requirements formulated by students, teachers and employers; b) Personal qualities, values and categories: tolerance; activity; attitude to cooperation; attitude to self-development. c) Skills: critical thinking; Making decisions; teamwork; communicativeness, knowledge of information technologies. d) Knowledge: problem orientation; interdisciplinarity of knowledge; interactive approaches to cognition; connection with reality and everyday life.

The expected effect of the system is formulated as follows: The system should stimulate everyone to strive for quality. The results should be linked to the management: the units of higher quality should receive a higher budget and vice versa. Such quality assurance system is an emanation of the structure and development of the European Higher Education Area combined with the imperatives of the Bologna Declaration. In that way the main direction of academic evolution towards providing conditions for achieving the main aspirations of the students - convertibility of diplomas, competencies and career opportunities in the European and global labour market.

\subsection{The Role of the National Accreditation Agency for the Regulation of Distance Learning in Bulgaria's Higher Education System}

The creation of rules, tools and mechanisms for distance learning is a basic prerequisite for its effective implementation. This is especially necessary in a pandemic situation, when distance learning becomes a basic form of education, providing a higher level of biological security for students and trainers. Not without reason are the claims that "self-isolation and the need to maintain social distance have brought distance learning to a fundamentally new level" (Kupchina, 2021, p. 505).

Part of the management at national level of the process of quality distance learning is its objective assessment and control. The evolution and modernization of the regulatory framework and procedures, in accordance with the new realities and strategic goals of higher education in Bulgaria, is undoubtedly an essential part of its effectiveness. This research line also states the need for "reconsidering the legal framework for autonomy and accreditation and creating rating systems with a view to balanced 
management, control over resources and the development of academic potential". (Terziev, Lyubcheva, \& Mihailova, 2021, p. 657). This view is supported by the position that distance learning in Bulgaria is a platform for innovation in higher education (Zahariev A., 2014, p. 20) .

The National Agency for Evaluation and Accreditation (NEAA) is a specialized state body for evaluation, accreditation and quality control of the activities of higher education institutions. After the entry into force of the amendments to the Higher Education Act in Bulgaria from 04.06.2004, NEAA also carries out the activity of post-accreditation monitoring and control. In its reports, the Agency itself emphasizes its public responsibility to support the process of improving the quality of higher education, which is a "fundamental social imperative". (National Agency for Evaluation and Accreditation, 2021, p. 60).

The evaluation of the distance form of education in Bulgaria in the respective professional fields is carried out in two stages. The first of them focuses on assessing the established organization and environment for conducting and maintaining distance learning. Only In case of a positive assessment at this stage, is possible the procedure to move to second stage, which includes checking the fulfilment of the criteria for assessment of distance learning in the specialty of the respective accredited professional field.

The current criteria system according to which the evaluation procedures are conducted (effective from 01.01.2017) is in accordance with the Standards and guidelines for quality assurance in the European Higher Education Area - Part 1 (ESG - Part 1). The defined criteria correspond to the specifics of the accreditation procedure for assessment of distance learning. They are a key measure of a university's ability to apply European standards and guidelines for improving the quality of higher education. In particular, they are addressed to: (i) Quality Assurance Policy; (ii) Development and improvement of programs; (iii) Studentcentered teaching, learning and assessment; (iv) Admission, development, recognition and certification / graduation / of students; (v) Teaching staff; (vi) Learning resources and student support; (vii) Information management; (viii) Public information; (ix) Ongoing monitoring and periodic review of programs; (x) Cyclical external quality assurance.

The regulatory framework is not a rigid component of modern education policy. It is subject to changes and development, corresponding to the stage of the educational system in the particular country (Ershov \& Chernykh, 2021, p. 435). The assessment and control of the distance form of education in Bulgaria is undergoing changes in the direction of creating an academic culture aimed at intellectual progress and better professional realization of students.

As a main conclusion of the current accreditation system in Bulgaria it can be said that, the role of distance learning for expanding the opportunities for access to quality education has been validated. In the current pandemic environment, the ability of this type of training to reduce health risks and ensure a higher level of biosafety has come to the fore. Assessment and accreditation as a tool for achieving quality education in distance form should be developed and reflect the new realities and changes in the environment. An essential element is finding a balance between the synchronization of education at the pan-European / global level and the efforts for identity and specificity of each specific university.

\subsection{Current Status of Bulgarian Higher Education System and Distance Learning Accreditation (2016-2020)}

In the beginning of 2021 Bulgarian higher education system includes 52 accredited institutions including 8 academies, 3 colleges, 30 universities and 11 Higher schools with the equivalent of the academies. Among them with accredited status for distance learning specialties and masters's programs are following institutions: Burgas Free University (with 4 distance specialties / master's programs), Varna Free University "Chernorizets Hrabar" (with 14 distance specialties / master programs), University of Veliko Tarnovo "St. St. Cyril and Methodius" (with 29 distance specialties / master's programs), Higher School of Agribusiness and Regional Development Veliko Tarnovo (with 6 distance specialties / master's programs), Higher School of Insurance and Finance (with 12 distance specialties / master programs), Varna University of Economics (with 10 distance specialties / master's programs), College of Business Administration (with 15 distance specialties / master's programs), Medical University - Pleven (with 1 master's programs), International Business School (with 12 distance specialties / master's programs), National Sports Academy - Vasil Levski (with 3 master's programs), New Bulgarian University (with 22 distance specialties / master's programs), Angel Kanchev University of Ruse (with 7 distance specialties / master's programs), Sofia University "St. Kliment Ohridski (with 10 distance specialties / master's programs),, "D. A. Tsenov" Academy of Economics Svishtov (with 1 master's program), University of National and World Economy (with 11 distance specialties / master programs) and University of Library Studies and Information Technologies (with 4 distance specialties / master's programs). 
For the last five years from the 2016 to 2020 the total number of students significantly dropped due to the governmental policy of reduction of approved admissions to universities in the fields of social sciences, law, economics, administration and management (See Table 1). The ratio of total number of students to total population of the country dropped from $3.51 \%$ in 2016 to $3.18 \%$ in 2020 . The opposite trend is with the ratio of total number of graduates from secondary school to the total number of students in BSc, MSc and PhD degrees where the ratio of $18.03 \%$ in 2016 accumulates to a level of $21.57 \%$ in 2018.

Table 1. Analytical data for the number of student, number of graduates from secondary school and total population of Republic of Bulgaria for the period $2016-2020$

\begin{tabular}{|c|c|c|c|c|c|}
\hline & $\begin{array}{c}\text { Total number of } \\
\text { students in BSc, } \\
\text { MSc and PhD } \\
\text { degrees }\end{array}$ & $\begin{array}{c}\text { Total number of } \\
\text { graduated } \\
\text { secondary } \\
\text { school }\end{array}$ & $\begin{array}{c}\text { Total population } \\
\text { of the country }\end{array}$ & $\begin{array}{c}\text { Ratio } \\
(1) /(3)\end{array}$ & $\begin{array}{c}\text { Ratio } \\
(2) /(1)\end{array}$ \\
\hline 2016 & 249600 & 45000 & 7101859 & $3.51 \%$ & $18.03 \%$ \\
\hline 2017 & 236700 & 48300 & 7050034 & $3.36 \%$ & $20.41 \%$ \\
\hline 2018 & 229500 & 49500 & 7000039 & $3.28 \%$ & $21.57 \%$ \\
\hline 2019 & 226600 & 47400 & 6951482 & $3.26 \%$ & $20.92 \%$ \\
\hline 2020 & 219800 & 45100 & 6916548 & $3.18 \%$ & $20.52 \%$ \\
\hline Average & 232440 & 47060 & 7003992 & $3.32 \%$ & $20.29 \%$ \\
\hline
\end{tabular}

Source: Ministry of Education and Science of the Republic of Bulgaria and National Statistical Institute

\subsection{The New National Ordinance for Distance Learning in Bulgaria as in Medias Answer of Covid-19 Pressure to Higher Education Institutions}

The Covid-19 pandemic, as well as current trends in digital technology, combined with strategic documents at national and European level, logically necessitate an update of the regulatory framework for distance learning in EU countries and in particular in Republic of Bulgaria. Based on one-year discussions within a working group of representatives of the Ministry of Education and Science, the National Centre for Distance Learning and leading universities in terms of experience and technology, a new Ordinance on state requirements for organizing distance learning in of higher education has been developed and adopted in 2021. The ordinance is also coordinated with the National Agency for Evaluation and Accreditation. The role of the agency is to assess the distance form of education in two stages - assessing the level of the environment in the respective higher school and assessing the opportunities for conducting distance learning in a specific professional field or specialty of the regulated professions.

The new ordinance published in the State Gazette in March 2021 (in force since September 1, 2021) provides a new definition of the distance form of higher education, which is specified in three separate paragraphs. It is defined that "distance learning is a form of higher education in which students, teachers and administrators can be separated by location, but not necessarily by time, as the distance created is compensated by technologies, methods and means of e-learning". The role of digital technologies has been introduced - "Distance learning is realized through digital technologies for managing the learning process, based on a system of different type, location and time of use of human, material and information activities and resources." The process approach is integrated in the teaching - "To compensate for the distance, the higher schools model the respective educational and administrative activities as information processes and implement them through information and communication technologies."

In addition to award higher education degrees, higher education institutions are allowed to organize distance learning and to improve the qualification of specialists with higher education, as well as for continuing and additional professional training. In view of the degree of information and technological provision in the implementation of distance learning, the environment for its implementation is classified into four levels. They are bound by the right to conduct training for the acquisition of the relevant degrees for higher education. 
The possibility for remote conducting of semester and state exams and videoconference defence of diploma theses is regulated.

The new Ordinance from 2021 introduces mandatory elements and conditions for the information infrastructure of higher education institutions, as follows: (1) internal rules for organization, conduct and development of distance and e-learning; (2) scientific research, teaching, administrative, and technical staff with competencies in the field of distance and e-learning; (3) a service unit for distance learning specially created at the higher school; (4) standards and procedures for the design, creation and licensing of elearning activities and resources in accordance with a methodology specific to e-learning and distance learning and in accordance with the Copyright and Related Rights Act; (5) electronic learning and administrative activities; (6) a repository of e-learning courses, activities and resources, including e-test units and tests; (7) systems for the management of electronically based assessments and final tests with the establishment of attempts at plagiarism and with the storage of examination data and student work in an electronic archive for at least 5 years; (8) system for identification of students and control of the respective procedures - in the cases of electronic conducting of examinations and assessment; (9) distance learning software platforms with synchronous and asynchronous learning capabilities and remote authorized permanent access for trainees, teachers and administrators.

The new Ordinance is based on the idea of practical-orientated concept of professional education (Diachok, Chernukha, Tokaruk, Udovenko, \& Petrova, 2020, p. 272) and training of specialists that are ready for real and public sector of the economy (Zagorodnya, et al., 2020, p. 139). The philosophy of all changes is to support the revolution for the Universities in $21^{\text {st }}$ century as an active corporate unit with educational and research services delivered to all over the world (Terziev V. , 2019, p. 324) and students with preparation according the real demand of the labour market - domestic and international (Terziev \& Ivanov, 2020, p. 6).

\section{CONCLUSION}

As a result of the new regulation of distance learning in Bulgarian higher education system, introduced in medias of Covid-10 pandemic, a triple positive effect was achieved. Students increase their digital skills for working in an electronic environment (Terziev V. , 2020b, p. 67). It has a positive effect on teachers as qualification and skills for work through the means of e-learning, lecture courses are digitalized. Higher education institutions implement simultaneously the government policy for increasing the quality of education, the efficiency in the organization of the educational process and the administrative activities. Finally, the national information and educational infrastructure is being improved, which helps to connect them in European and global networks for higher education. The main conclusion of the study is that the Covid-19 and the new regulation of distance learning pushed forward all Bulgarian universities on the road of fast digitalization and introduction of the most advanced e-learning technologies.

\section{ACKNOWLEDGEMENT}

This research was financially supported by the Academic Foundation "Prof. Dr. Minko Rousenov", Svishtov, Bulgaria (Grant No. 1001006) and the Institute of Scientific Research at D. A. Tsenov Academy of Economics, Svishtov, Bulgaria.

\section{REFERENCE LIST}

Ershov, B., \& Chernykh, V. (2021). EDUCATIONAL POLICY OF RUSSIA IN THE FIELD OF HIGHER EDUCATION. Abstracts \& Proceedings of INTCESS 2021-8th International Conference on Education and Education of Social Sciences, 18-19 January, 2021 (pp. 434-437). ISBN: 978-605-06286-1-6: DOI: https://doi.org/10.51508/intcess.2021151.

Diachok, N., Chernukha, N., Tokaruk, L., Udovenko, I., \& Petrova, M. (2020, August). Practical-oriented concept as a principle of professional education of the future professionals. International Journal of Higher Education(4), 272-282. doi:https://doi.org/10.5430/ijhe.v9n4p272

European Training Foudation. (1999). Phare Multi-Country Programme for Distance Education. Programme Compendium. Retrieved 3 10, 2020, from ERIC: https://eric.ed.gov/?id=ED438452

Kupchina, E. (2021). DISTANCE EDUCATION DURING THE COVID-19 PANDEMIC. Abstracts \& Proceedings of INTCESS 2021- 8th International Conference on Education and Education of Social Sciences, 18-19 January, 2021 (pp. 505-510). ISBN: 978-605-06286-1-6: DOI: https://doi.org/10.51508/intcess.2021142. 
National Agency for Evaluation and Accreditation. (2021, 05 26). SAMOOTSENYAVASHT DOKLAD NA NATSIONALNATA AGENTSIYA ZA OTSENYAVANE I AKREDITATSIYA (NAOA) ZA VUNSHEN PREGLED OT EVROPEISKATA ASOTSIATSIYA ZA OSIGURYAVANE NA KACHESTVOTO VUV VISSHETO OBRAZOVANIE / ENQA/, Sofia, 2017. Retrieved from National Agency for Evaluation and Accreditation: https://www.neaa.government.bg/images/events/Doklad_SO_NAOA2017-ENQA.pdf

Terziev, V. (2019). The role of business in society. Proceedings of SOCIOINT 2019, 6th International Conference on Education, Social Sciences and Humanities, 24-26 June 2019 (pp. 324-330). Istanbul, Turkey: International Organization Center of Academic Research.

Terziev, V. (2020b). New strategy for higher education for 2021-2030 in Bulgaria and challenges for its implementation. 60th International Scientific Conference on Economic and Social Development - XX International Social Congress (ISC 2020), 60, pp. 67-75. Moscow. Retrieved from https://www.researchgate.net/publication/345437242

Terziev, V., \& Ivanov, I. (2020). The national employment plan in Bulgaria - analysis and opportunities for change. International scientific journal „Internauka", Kiev, Ukraine, 15(95), 6-13.

Terziev, V., Lyubcheva, M., \& Mihailova, K. (2021). THE NECESSITY OF CHANGES IN THE HIGHER EDUCATION IN BULGARIA. Abstracts \& Proceedings of INTCESS 2021- 8th International Conference on Education and Education of Social Sciences, 18-19 January, 2021 (pp. 646-657). ISBN: 978-605-06286-1-6: DOI: https://doi.org/10.51508/intcess.202104.

Zagorodnya, A., Dichek, N., Chobitko, N., Voznyk, M., Honchar, L., \& Petrova, M. (2020, June). Professional training of the economic sector specialists at higher education institutions of the Republic of Poland and Ukraine: criteria of comparison. International Journal of Higher Education, 9(4), 139-144. doi:https://doi.org/10.5430/ijhe.v9n3p139

Zahariev, A. (2009). A New Impetus for Development of the Academic Thinking. Narodnostopanski Arhiv, LXII(International Edition), 5-7.

Zahariev, A. (2014). Distantsionnoto obuchenie v Bulgariya - platforma za inovatsii vuv vissheto obrazovanie. Sbornik dokladi ot Peta natsionalna konferentsiya po elektronno obuchenie vuv visshite uchilishta (pp. 19-28). Russe: Akademichno izdatelstvo na Rusenski universitet "Angel Kunchev".

Zahariev, A., \& Zaharieva, G. (2003, September). HR management in Bulgarian firms - empirical evidences. Dialog(3), 5-36. doi:10.2139/ssrn.2977326 